\title{
Concerning suffering: Philosophical perspectives in the current Novel Corona Virus Disease (COVID-19) Outbreak
}

\section{Christine Carmela R. Ramos}

Mapua University, Philippines

Article History: Received:11 January 2021; Accepted: 27 February 2021; Published online: 5 April 2021

Abstract: Humanity's basic virtue is the recognition and acceptance of reason as a guide to action. In this vein, this paper contributes to the reader a better understanding of existence as this paper analyses the different views of suffering and coping, which also includes the reflections and examples of the author. Though happiness is the moral purpose of life, this research lays the groundwork for realization as we affirm the reality of suffering, especially in the present challenges of the Corona Virus 19 pandemic. As humans, we need not inhibit ourselves but rather affirm our potentialities.

This research uses parallelism of philosophies, both Western and Eastern that expounds and argues on human adaptation vis-à-vis suffering that can be seen as antagonistic or can fulfill our potentialities. Further, the philosophical views can be viewed in a holistic approach - metaphysical, psychological, and ethical. This paper unfolds important questions that contribute to the quest for philosophical truth, broadening and deepening the meaning of life at the present predicament. Finally, amidst the world's dust and grime, this work imparts compassion, care, optimist, and hope.

Keywords: Coping, Faith, Suffering, Eastern Viewpoints, Western Outlooks

\section{INTRODUCTION}

Our World today is full of suffering. Today we reach another year of commemorating the COVID-19 pandemic that reverberated to the entire world. Aside from this, people in most countries suffer from hunger, from violence, while others suffer from diseases or disabilities. Meditating on suffering which is one of the most central in our lives, this paper reflects on common adversities such as:

- Stress

- Anxiety

- Disappointment

Major life changes that bring suffering and great hardships are:

- Job loss

- Accidents

- Disease

- Death of a loved one

Everyone suffers and has problems in life. Most of us find ways to end these sufferings. Being right or doing what is right is the answer for most people especially those who have faith in their religions.

\section{PROBLEM STATEMENT}

In this research, the author clarifies and discusses the concepts of suffering creating new inquiries and meditating on afflictions regarding the effects of COVID-19 to present experiences. However, this paper does not dwell on suffering alone but with attention to a search for enlightenment towards authentic awareness of our nature: both the innermost self and trying to get along with others that recognize the dignity and feelings of the human person. In this respect, the author is faced with Carl Jasper's encounter of the so-called boundary situations. These are death, suffering, guilt, and struggle (Jaspers, 2012).

Questions such as "What am I living for?" and "What do I live by?" guide the reflective process of this humble work. The aims of this paper and questions posed are valuable for they attempt to elevate persons not as faceless entities or as part of a survey, but as persons who could be better and more productive. 


\section{METHODS}

This research draws parallelism of philosophies. There are two major philosophical views regarding human suffering: First, physical pain refers to physical sensations such as discomfort, hunger, distress, and pain. Secondly, mental suffering is associated with emotional and mental conditions such as despair, apprehension, anxiety, isolation, and pain (ennui or angst).

From a philosophical viewpoint, there are different ways of thoughts. The philosophical basis of the West, for instance, is the individual, while the Eastern encompassed the whole. The West indicated that the person is responsible for what becomes of him. To be an individual is to choose what he wants to be, regardless of others' expectations (Ramos, 2017: 2).

Moreover, the East focused on moral reform which can begin only with the self (Kaplan, 1961: 275). The East further viewed the individual as dynamic and relational (Moore, 1983). In the East, the self is dissolved as well as other people into conglomerations of personal and instantaneous elements. In other words, from a theological perspective, there is reciprocity between philosophy and faith in the East. Mclean (1955: 216) regarded the community and the individual as both necessary components in life. According to him, only through relations with others can the individual concretely express oneself.

\section{FINDINGS AND DISCUSSIONS}

\subsection{Views about suffering}

- One view considers suffering as an undesirable human condition, and that humans naturally seek pleasure and avoid pain. The Greek Philosophers believed that suffering can be avoided by seeking pleasurable things or activities, or through the exercise of self-control. Having too much suffering or happiness will result in a warped sense of reality which will lead to confusion and anxiety. Cognition is accounted for actions and no other forces.

- Another major perspective states that suffering is necessary for human existence.

Buddhist philosophy considers suffering as a defining feature of human existence. The four noble truths advise that human misery is caused by selfish cravings. It follows that suffering will only end through the eradication of worldly yearnings. The Buddhists practice the four states of sublime condition: love, the distress of others, joy in the joy of others, and calmness as regards one's joy and sorrows that should be practiced. Comparable to Hinduism, as well as other beliefs, Buddhism is a matter of practice (Mclean, 1970: 41).

- Hinduism believes that suffering is closely tied to spiritual progress and that all suffering ends when a person attains enlightenment. In Hinduism, for instance, the Vedantist observe the three stages to commune (Van Over, 1977: 47). Faith, reason, and experience. Faith is the phase where we simply admit the laws of nature as a manifestation of divine existence. Suffering is an end, but with faith, it is a doorstep to a new life (Areno, 2021). The reason is the second route where the seeker tries to recognize these laws by rational and logical methods.

God, however, is beyond the power of any created intellect to grasp. However, the only experience can the limitation of faith and reason can be completed. Moreover, through experience, the seeker perceives the illusory veil covering Brahman. The Indian's notion of Brahman has parallelism with Christianity. As argued by Ludwig Feuerbach, a person is God and God is in the person.

There is no distinction between God and human beings. It follows that, in Christianity, God's solidarity with humanity is in all our sufferings. We are dealing with a paradox; suffering is not according to human wisdom but based on God's "foolishness."

- Suffering is essential because it defines human existence.

Without it, humanity is unable to grow and improve, and his/her positive experiences or life may lose meaning and significance. For the Filipino's indigenous view, there is a holistic concept or non-dual outlook of the world. The Filipinos' Christian concept is connected with the Creator who deepened one's reality of life.

In response, in dealing with adversities in life, a person cannot solve any great problems if not seen in the light of others. Since as individuals and social beings, we are not necessarily separate entities. As individuals, we are socially responsible, because ultimately, we are affected by much bigger realities. It can be inferred that the individual also actively participates in whatever happens to one's self and society. A good influencer can motivate people to achieve 
success, to regard themselves in positive light amidst misfortunes, obstacles, and unpredictability of life, and bounce back.

\subsection{Accordingly, there are ways of coping that range from positive processes such as:}

- Anticipating and preparing for stress

- Seeking support from other people

- Implementing stress management through physical activity, relaxation, constructive emotional release, and humor.

As a result, however, others cope with adversity through negative channels such as:

- Withdrawal

- Avoidance

- Escapism

- Believe that suffering can be avoided by seeking only the pleasurable things in life and avoiding those that cause harm or pain.

\subsection{Philosophers' views about coping}

- The Stoics believe that one must face difficulties in life with fortitude and patience.

- For Nietzsche, a person should not blame other people or look at external factors to explain his or her suffering. A person should face his or her suffering and take responsibility for it.

- Utilitarian philosophers argued that to alleviate suffering in the world, people should focus on actions that are beneficial to society. This view is supported by humanitarianism. For example, how the economy will grow in decreasing production due to the COVID 19 pandemic. The extension of Enhanced Community Quarantine or ECQ has seen in the effects of our daily lives and also in the environment wherein pollution in Metro Manila went down because of the limited vehicles causing the recovery of the environment. Further, utilitarian argued that the purpose of a person's existence is to make other people happy.

Dealing with suffering and adversity is understood in various studies that determine that people recover from traumatic experiences more quickly if adequate social support is available. The political decisions during the lockdown in the Philippines, caused some to be happy because of the benefits they will get because of more time in family bonding that one was not able to experience in the past years due to being busy in one's field of work. However, others disagree to the extended ECQ or lock down because they are not having any income but experienced hunger and emptiness.

During this period of quarantine, a person can deal with stress and difficulties better if he or she knows that people around are willing to support him/her. He/she can blossom in a society in a participative atmosphere toward transformation.

Family is the main source of emotional boost in times of crisis. Peer groups support because they often have the same background and experiences, and their shared views often lead to good advice. Religious groups also offer faith and prayer as opportunities for reflection and sympathy which are needed, whether online or through other means. In Christianity, for instance, the community itself is the oldest and most important liturgical sign stressed.

The virtual world can affect your emotions which is very significant, as well as your mental condition and sometimes social wellness, but it will never fully support other dimensions of wellness like spiritual, environmental, and physical. We can write all our beliefs and publish them on the internet but the faith in people, the feelings for what we believe in will never take place of our technologies. However, some communities might have no strong data connection, that others should go to the tower far from their homes just to have a signal.

As technologies continue to develop very fast and produce different types of computer/applications as alternatives, due to the high demand for online activities, they may tend to derive happiness in people, but the author does not think it would make people contented and satisfied.

\section{CONCLUSION}

As Filipinos, we accept what we cannot completely control such as natural calamities and death. Rather, we see the person as master of one's ship in a sea that is not entirely devoid of uncertainties (Ordonez, 1986). Suffering is a great lesson for living and learning. For this reason, suffering provides invaluable lessons amid the world's dust and 
grime. It is not a stumbling block but beyond human wisdom. As we are caught up in a world that can be lacking mercy, we must come to realize and experience more significant lessons at home and beyond borders.

Through suffering, we have a mission to continue - to be compassionate for humanity, value sensitivity to the needs of others, and gratitude. In conclusion, the author ends with passages from poetry depicting the true reflection of the current pandemic experience around the globe that also serves as an inspiration to our soul.

Invictus

(William Ernest Henly, 2021)

Beyond this place of wrath and tears

Looms but the Horror of the shade,

And yet the menace of the years

Bibliography

Finds, and shall find me, unafraid.

1. Areno, Ruben. March 21, 2021. The "hour" has come. Sambuhay. Missalette. Makati. St. Paul's Media Ministry.

2. Henly, William Ernest. (2021). Invictus. Poetry Foundation. Retrieved from: https://www.poetryfoundation.org/poems/51642/invictus.

3. Jasper, Karl. 2012. Boundary situations. Brill | Rodopi. https://www.google.com/search?q=karl+jaspers+boundary+situations+latest\&rlz=1C1GCEU_enPH889 PH889\&ei=SVtVYN_pNsv7QbBuZPwBw\&oq=karl+jaspers+boundary+situations+latest\&gs_lcp=Cgdnd3Mtd216EAMyBQghEKA BMgUIIRCgATIFCCEQoAE6BQgAELADOgYIABAWEB46CAghEBYQHRAeOgcIIRAKEKABU M4fWNYoYJYqaAFwAHgAgAFsiAHhBZIBAzYuMpgBAKABAaoBB2d3cy13aXrIAQHAAQE\&scl ient=gws-wiz\&ved=0ahUKEwifstGB573vAhXLfd4KHcHcBH4Q4dUDCA0\&uact=5

4. Kaplan, Abraham. (1961). The New World of philosophy. New York. Vintage books.

5. Mclean, George. (1970). Philosophy and Christian theology. Washington, DC. Catholic University of America.

6. Moore, Charles. (1983). The status of the individual in the East and West. Honolulu. University of Hawaii Press.

7. Ordonez, Marcelo. (1986). People Power: A demonstration of emerging Filipino Ideology. Quezon City. Sampaguita Printing Press.

8. Ramos, Christine. (2017). Introduction to philosophy of the human person. Quezon City. Rex Bookstore, Inc.

9. Smith, Margaret. (1978). The way of the mystics: The early Christian mystics and the rise of the Sufis. New York. Oxford University Press.

10. Van Over, Raymond. (1977). Eastern Mysticism. New York. Mentor.

\section{Acknowledgments:}

To my family, thank you very much for the love. To colleagues and friends at Mapúa University, a huge thanks for the support. To God, thanks for this unique journey! 